American Journal of Applied Sciences 5 (9): 1135-1140, 2008

ISSN 1546-9239

(C) 2008 Science Publications

\title{
The Serviceability Considerations of HSC Heavily Steel Reinforced Members under Bending
}

\author{
${ }^{1}$ Ali Akbar Maghsoudi and ${ }^{2}$ Yasser Sharifi \\ ${ }^{1}$ Department of Civil Engineering, Bahonar University of Kerman, Kerman, Iran \\ ${ }^{2}$ Department of Civil Engineering, Vali Asr University of Rafsanjan, Rafsanjan, Iran
}

\begin{abstract}
To investigate the serviceability conditions of High Strength Concrete (HSC) beams, the total number of 6 beams $(\mathrm{L}=2 \mathrm{~m}, \mathrm{~b}=0.2 \mathrm{~m}, \mathrm{~h}=0.3 \mathrm{~m}$ ) heavily reinforced with different ratios of $\rho$ and $\rho^{\prime}$ were cast and tested under bending load. During the test the concrete and steel strains, deflection and crack width are measured at different beam locations. Based on these experimental readings, the bending rigidities (EI) of HSC beams are defined and the results are compared with the different available theoretical methods.
\end{abstract}

Key words: HSC beams, different ratios of $\rho$ and $\rho^{\prime}$, serviceability conditions, EI

\section{INTRODUCTION}

Despite a large number of investigations ${ }^{[1-6]}$ carried out in the past on flexural behavior of high strength concrete (HSC) beams, controversy still remains with regard to some vital design issues. One such issue is the serviceability requirement of cracks. Beams tested by several investigators consistently demonstrated significantly larger deflections at service load than what would be predicted by following the ACI $318-02^{[7,8]}$ provisions. Rashid ${ }^{[9]}$ believe that, ever the assumption of cracked moment of inertia as the effective value and use of the representative expressions for the elastic modulus of concrete as reported by ACI committee $363^{[8]}$ for HSC had failed to bring the predictions on the conservative side. Majority of explanations investigations reported are based on the underreinforced HSC, In other words, the serviceability considerations of HSC heavily steel reinforced members are not investigated. Therefore, must be sought through further investigations on this field. The result of an investigation carried out on flexural behavior of reinforced HSC heavily reinforced beams, with a wide range of variation in compressive reinforcement are presented in this research. After the cracking moment the neutral axis fluctuates between cracks and causing the value of I changes along the beam span from a maximum value of $I_{g}$ for the uncracked (gross) section to a minimum value of $I_{\text {cr }}$ for the fully cracked (transformed) section. Therefore in cracked member, using an effective moment of inertia,
$I_{e}$ that will have a value between cracked and uncracked section's value. Design provisions contained in the current code ${ }^{[8]}$ recommend use of following expression for the calculation of the effective moment of inertia:

$$
I_{e}=\left(\frac{M_{c r}}{M_{a}}\right)^{3} I_{g}+\left[1-\left(\frac{M_{c r}}{M_{a}}\right)^{3}\right] I_{c r}
$$

Where

$\mathrm{M}_{\mathrm{a}}=$ maximum moment in a member at a stage that deflection is computed.

$\mathrm{M}_{\mathrm{cr}}=$ cracking moment of beam $=\frac{\mathrm{f}_{\mathrm{r}} \mathrm{I}_{\mathrm{g}}}{\mathrm{y}_{\mathrm{t}}}$

\section{EXPRIMENTAL PROGRAM}

Test specimens: The program consisted of testing six heavily reinforced HSC beams tested in flexure. The details of test beams are presented in Table 1 and Fig. 1. Three beams were singly reinforced and the other three were doubly reinforced. Shear reinforcements were provided along the beam length except in the constant moment region. The variable was the compressive reinforcement ratio, $\rho^{\prime}$. Table 1 presents the detailed testing program, where one or two letter followed by a number, such as BC6 or B6, designate the specimens. The letters $\mathrm{BC}$ indicated the beams having compression bars too. The numeral 6 to 8 indicates the variation on $\rho$ and $\rho^{\prime}$.

Corresponding Author: Ali Akbar Maghsoudi, Department of Civil Engineering, Bahonar University of Kerman, P.O. Box 76169-14111, Kerman, Iran 
Am. J. Applied Sci., 5 (9): 1135-1140, 2008

Table 1: Testing program detail of the tested beam

\begin{tabular}{lllllll}
\hline$\rho^{\prime} / \rho$ & $\mathrm{A}_{\mathrm{s}}^{\prime}$ & $\mathrm{A}_{\mathrm{s}}$ & $\mathrm{d}^{\prime}(\mathrm{mm})$ & $\mathrm{d}(\mathrm{mm})$ & $\mathrm{f}_{\mathrm{c}}^{\prime}(\mathrm{MPa})$ & $\mathrm{Beam}$ \\
\hline 0.5 & $2 \Phi 28$ & $4 \Phi 28$ & 40 & 256 & 73.65 & BC6 \\
0.0 & - & $4 \Phi 28$ & - & 256 & 71.00 & B \\
0.5 & $3 \Phi 22+2 \Phi 14$ & $4 \Phi 28+2 \Phi 16$ & 57 & 266 & 66.81 & $\mathrm{BC} 7$ \\
0.0 & - & $4 \Phi 28+2 \Phi 16$ & - & 266 & 70.50 & $\mathrm{~B} 7$ \\
0.5 & $2 \Phi 28+2 \Phi 14+1 \Phi 16$ & $2 \Phi 28+6 \Phi 22$ & 59 & 258 & 77.72 & $\mathrm{BC}$ \\
0.0 & - & $2 \Phi 28+6 \Phi 22$ & - & 258 & 71.80 & $\mathrm{~B} 8$ \\
\hline
\end{tabular}

Table 2: Concrete mix proportion

Cement Microsilica Coarse agg Fine agg Super-plasticizer W/C

\begin{tabular}{llllll}
$\left(\mathrm{kg} \mathrm{m}^{-3}\right)$ & $\left(\mathrm{kg} \mathrm{m}^{-3}\right)$ & $\left(\mathrm{kg} \mathrm{m}^{-3}\right)$ & $\left(\mathrm{kg} \mathrm{m}^{-3}\right)$ & $\left(\mathrm{kg} \mathrm{m}^{-3}\right)$ & ratio \\
\hline 649 & 55 & 723 & 646 & 11 & 0.32
\end{tabular}
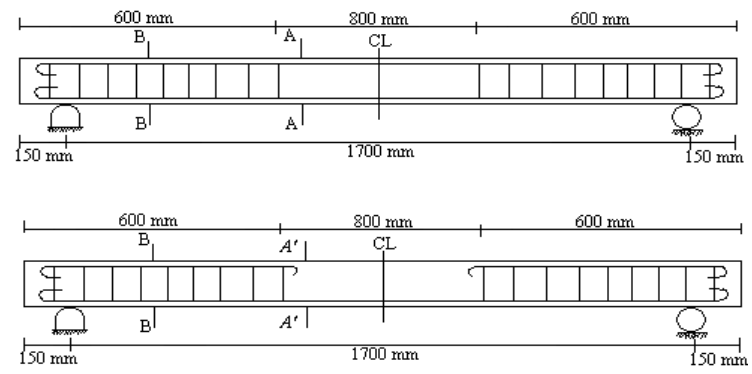

Fig. 1a: Details of test beams

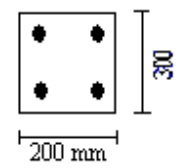

SECTION A-A

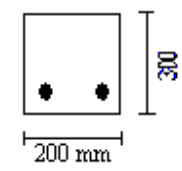

SECTION $A^{t}-A^{t}$

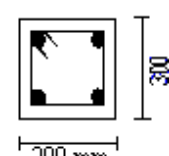

$200 \mathrm{~mm}$
Fig. 1b: Details of beam sections

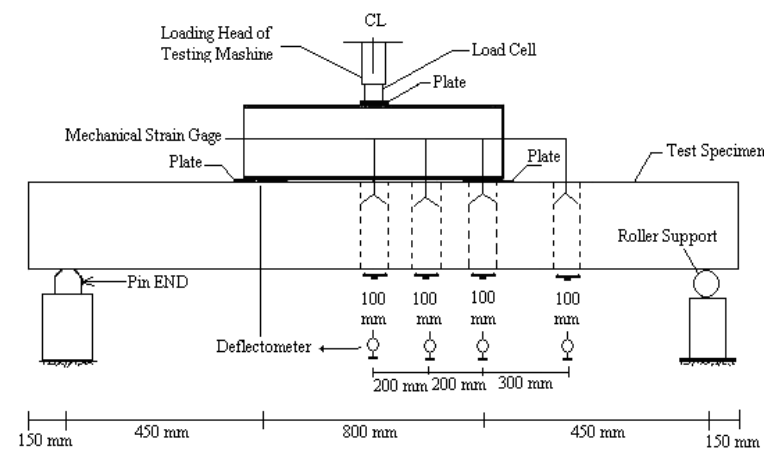

Fig. 1c: Testing arrangement

Materials: Locally available deformed steel bars having yield strength of $400 \mathrm{MPa}$ were used as flexural reinforcement. The mix design is shown in Table 2. All beams and control specimens were cast in steel molds and demolded the next day and cured under similar humidity conditions for at least 28 days.
Test procedure: The test beams were simply supported and subjected to four - point loading system over a span of $1700 \mathrm{~mm}$, as shown in Fig. 1. The beam midspan deflection was measured with the help of deflection transducers $\left(\mathrm{LVDT}_{\mathrm{S}}\right)$. Strains in the tension and compression steel were measured by electrical strain gauges mounted on them. Compressive strains at the surface of the concrete beams were measured with electrical and mechanical (demec) strain gauges fixed at different critical locating including the midspan Fig. 1. The surface concrete crack widths at constant moment zone at the centerline near the bottom layer of tensile steel were measured within the central $800 \mathrm{~mm}$ length for any load increments with an accuracy of $0.02 \mathrm{~mm}$. load was applied by means of a $1400 \mathrm{kN}$ hydraulic testing machine. During test, the measurements were taken by data logger.

\section{EXPERIMENTAL RESULTS AND DISCUSSIONS}

Cracking and Yield Moments: The obtained experimental cracking and yield moments are presented in Table 3 The experimental cracking moments, $\mathbf{M}_{\text {cr,exp }}$, are calculated and compared with the corresponding moments calculated by using two different code approaches, ACI and $\mathrm{CSA}^{[8,10]}$ for the beams tested in this research. Cracking moment is estimated using the modulus of rupture as:

$$
M_{c r} \frac{f_{r} I_{g}}{y_{t}}
$$

Where

$f_{r}=$ Modules of rupture of concrete and their values for the two Codes are presented as:

$$
\begin{array}{ll}
\mathrm{f}_{\mathrm{r}}=0.62 \sqrt{\mathrm{f}_{\mathrm{c}}^{\prime}} & \mathrm{MPa}(\mathrm{ACI}), \\
\mathrm{f}_{\mathrm{r}}=0.6 \lambda \sqrt{\mathrm{f}_{\mathrm{c}}^{\prime}} & \mathrm{MPa}(\mathrm{CSA}) \\
\mathrm{f}_{\mathrm{r}}=0.63 \sqrt{\mathrm{f}_{\mathrm{c}}^{\prime}} & \mathrm{MPa}^{[5]} .
\end{array}
$$

$\mathrm{y}_{\mathrm{t}}=$ Distance of the extreme tension fiber from the neutral axis

$\lambda=1$ for concrete with normal density 
Am. J. Applied Sci., 5 (9): 1135-1140, 2008

Table 3: Experimental cracking and yield moments

\begin{tabular}{lllllllll}
$\begin{array}{l}\text { Beam } \\
\text { No. }\end{array}$ & $\begin{array}{l}\mathrm{M}_{\text {y(exp) }} \\
(\mathrm{kN} . \mathrm{m})\end{array}$ & $\begin{array}{l}\mathrm{M}_{\text {cr(exp) }} \\
(\mathrm{kN} . \mathrm{m})\end{array}$ & $\begin{array}{l}\mathrm{M}_{\text {cr(th-ACI) }} \\
(\mathrm{kN} . \mathrm{m})\end{array}$ & $\begin{array}{l}\mathrm{M}_{\text {cr(th-CSA) }} \\
(\mathrm{kN} . \mathrm{m})\end{array}$ & $\begin{array}{l}\mathrm{M}_{\text {cr[5] }} \\
(\mathrm{kN} . \mathrm{m})\end{array}$ & $\begin{array}{l}\mathrm{M}_{\text {cr(exp) }} / \\
\mathrm{M}_{\text {cr(th-ACr) }}\end{array}$ & $\begin{array}{l}\mathrm{M}_{\text {cr(exp) }} / \\
\mathrm{M}_{\text {cr(th-CSA })}\end{array}$ & $\begin{array}{l}\mathrm{M}_{\text {cr(exp) }} / \\
\mathrm{M}_{\text {cr[5] }}\end{array}$ \\
\hline BC6 & 188.16 & 12.05 & 15.89 & 15.38 & 16.15 & 0.75 & 0.78 & 0.75 \\
B6 & 197.96 & 09.90 & 15.52 & 15.02 & 15.77 & 0.64 & 0.66 & 0.63 \\
BC7 & 234.03 & 11.31 & 15.20 & 14.72 & 15.44 & 0.74 & 0.77 & 0.73 \\
B7 & 141.75 & 10.79 & 15.47 & 14.96 & 15.72 & 0.69 & 0.72 & 0.68 \\
BC8 & 229.33 & 11.46 & 16.39 & 15.86 & 16.65 & 0.70 & 0.72 & 0.69 \\
B8 & 238.97 & 10.64 & 15.61 & 15.10 & 15.86 & 0.68 & 0.70 & 0.67 \\
\hline
\end{tabular}

Rashid and Mansure ${ }^{[9]}$ tested 16 reinforced HSC beams in flexure with concrete strength $f_{c}^{\prime}$, ratios of tensile and compressive reinforcements. ( $\rho$ and $\rho^{\prime}$, respectively) and spacing of lateral ties as the main parameters. They compared the obtained experimental cracking moments with the corresponding moments calculated by using different approaches ${ }^{[7,11-14]}$ for the beams tested. Different representative expression suggested by ${ }^{[7,11-14]}$ were testified while using Eq. (2). These are include, modulus of rupture, $\mathrm{f}_{\mathrm{r}}, \mathrm{E}_{\mathrm{c}}$ and the reduced modulus $\bar{E}_{c}$ equal to $E_{c} / 2$, together with gross section properties. It was found that the ACI $\operatorname{code}^{[7]}$ procedure for serviceability requirements of maximum crack width is adequate up to a concrete strength of approximately $130 \mathrm{MPa}$. Concerns However, are expressed regarding the adequacy of those for cracking moment and service load deflections.

It was shown that ${ }^{[11]}$, however the ACI expressive for $f_{r}$ is highly conservative for HSC. The first author of this research, tasted another 12 HSC beams in flexure with the main variable ratio of $\rho$ and $\rho^{\prime[5]}$ and it was found that a value of $f_{r}=0.63 \sqrt{\mathrm{f}^{\prime}}{ }_{c} \quad(\mathrm{MPa})$ for $\mathrm{f}_{\mathrm{r}}$ can predict the cracking moment with sufficient accuracy for first crack observed in HSC beams. The comparison of 6 HSC beams of this report with suggested values of ${ }^{[5]}$ are shown in Table 3 .

Neutral Axis Depth: The experimental neutral axis depth of tested beams obtained from the experimentally measured strain values on concrete surface and tensile steel reinforcement. The variation of ratio of neutral axis depth, c, to the effective depth of the section, $d$, in the constant moment zone is shown in Fig. 2 and experimental neutral axis depth at cracking, yield and ultimate loads are also shown in Table 4.

Cracked Moment of Inertia: The value of $I_{\exp }$ is assumed to approach $\mathrm{I}_{\mathrm{cr}(\exp )}$ when the applied moment approaches $\mathrm{M}_{\mathrm{y}}$, which is a realistic assumption ${ }^{[15]}$. The calculation of deflection during the service stage of structure depends mainly on the cracked moment of inertia, $\mathrm{I}_{\mathrm{cr}}$. The experimental moment of inertia $\mathrm{I}_{\mathrm{cr}(\exp )}$ is obtained as:
Table 4: Experimental neutral axis depth measured at cracking, yield

\begin{tabular}{llcc}
\multicolumn{4}{c}{ and ultimate loads } \\
\hline Beam No. & $\mathrm{C}_{\mathrm{cr}}(\mathrm{mm})$ & $\mathrm{C}_{\mathrm{y}}(\mathrm{mm})$ & $\mathrm{C}_{\mathrm{u}}(\mathrm{mm})$ \\
\hline BC6 & 148.2 & 98.2 & 48.2 \\
B6 & 159.5 & 102.50 & 99.00 \\
BC7 & 134.9 & 121.4 & - \\
B7 & 182.0 & 126.6 & 117.7 \\
BC8 & 114.3 & 112.5 & 50.3 \\
B8 & 168.5 & 150.4 & 115.3 \\
\hline
\end{tabular}
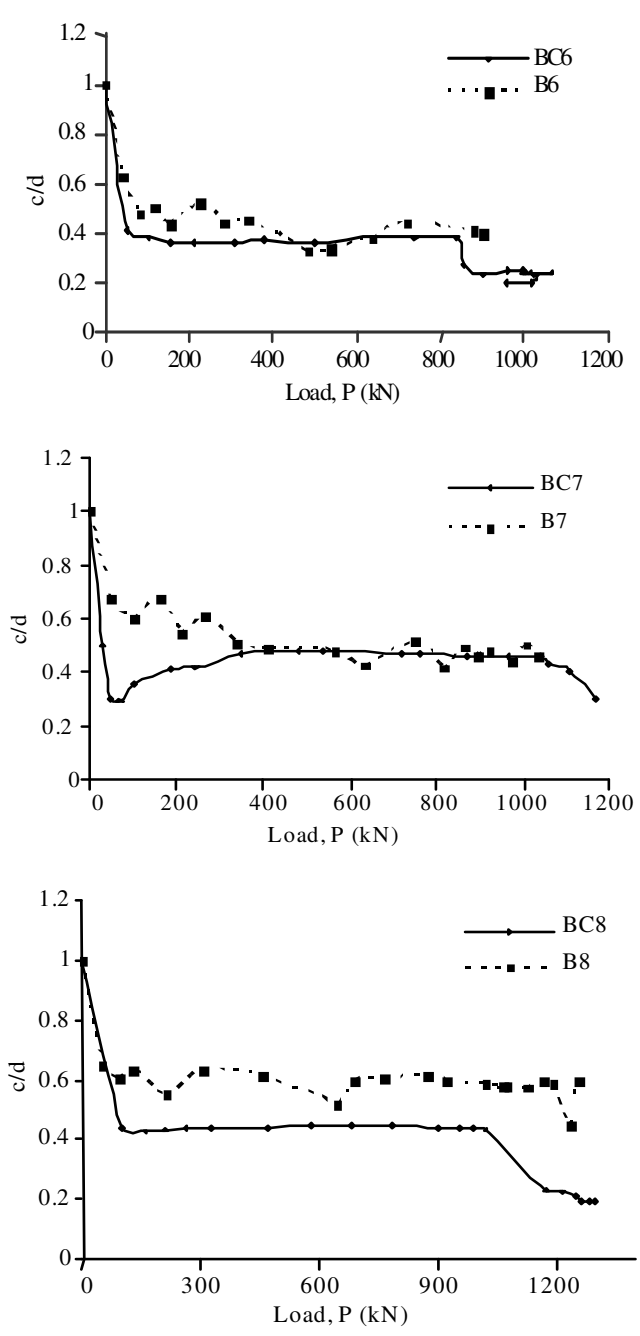

Fig. 2: Behavior of neutral axis depth under load for HSC beams tested 
Am. J. Applied Sci., 5 (9): 1135-1140, 2008

$$
\mathrm{L}_{\mathrm{cr}(\operatorname{expl} \mathrm{l})}=\frac{\mathrm{P}_{\mathrm{y}} \cdot \mathrm{a}\left(3 \mathrm{l}^{2}-4 \mathrm{a}^{2}\right)}{48 \mathrm{E}_{\mathrm{c}} \Delta_{\exp }}
$$

Where

$\mathrm{P}_{\mathrm{y}}=$ Load that causes tension reinforcement yield

$\mathrm{A}=$ Shear arm

$\mathrm{L}=$ Clear span of the beam

$\mathrm{I}_{\mathrm{cr}}$ cracking moment of inertia and it can also be defined as the slope of the line connecting the origin and point of initial yielding of tensile reinforcement in moment curvature curve ${ }^{[16,17]}$ and this is given as:

$$
I_{c r(\exp 2)}=\frac{M_{y}}{E_{c} \varphi_{y}}
$$

Where

$$
\varphi_{\mathrm{y}}=\frac{\varepsilon_{\mathrm{cy}}+\varepsilon_{\mathrm{sy}}}{\mathrm{d}}=\frac{\varepsilon_{\mathrm{cy}}}{\mathrm{c}}
$$

$\varepsilon_{\mathrm{cy}}=$ Measured compression strain in the concrete at yielding stage

$\varepsilon_{\mathrm{sy}}=$ Measured tensile strain in steel reinforcement at yielding stage

$\mathrm{C}=$ Neutral axis depth

The traditional theoretical definition of $\mathrm{I}^{\mathrm{cr}}$ based on the cracked transformed section can be given as: Beams with singly reinforcement

$$
\begin{aligned}
& \frac{b c^{2}}{2}+n A_{s} c-n A_{s} d=0 \\
& I_{c r}=\frac{b c^{3}}{3}+n A_{s}(d-c)^{2}
\end{aligned}
$$

Beams with doubly reinforced

$$
\begin{gathered}
\frac{b c^{2}}{2}+\left(A_{s}+A_{s}^{\prime}\right) n c-\left(A_{s} d+A_{s}^{\prime} d^{\prime}\right) n=0 \\
I_{c r}=\frac{b c^{3}}{3}+n A_{s}(d-c)^{2}+(n-1) A_{s}^{\prime}\left(c-d^{\prime}\right)^{2}
\end{gathered}
$$

Where

$\mathrm{n}=\mathrm{E}_{\mathrm{s}} / \mathrm{E}_{\mathrm{c}}$

\begin{tabular}{|c|c|c|c|}
\hline Beam No. & $\begin{array}{l}\text { Icr (th) }) \times 10^{6} \\
\left(\mathrm{~mm}^{4}\right)\end{array}$ & $\begin{array}{l}\text { Icr }\left(\exp _{1}\right) \times 10^{6} \\
\left(\mathrm{~mm}^{4}\right)\end{array}$ & $\begin{array}{l}\text { Icr }\left(\exp _{2}\right) \times 10^{6} \\
\left(\mathrm{~mm}^{4}\right)\end{array}$ \\
\hline BC6 & 452.98 & 183.95 & 385.84 \\
\hline B6 & 378.61 & 204.17 & 243.41 \\
\hline BC7 & 506.02 & 166.42 & 420.53 \\
\hline B7 & 453.73 & 188.85 & 326.00 \\
\hline BC8 & 513.79 & 199.67 & 421.29 \\
\hline B8 & 467.50 & 256.80 & 388.37 \\
\hline
\end{tabular}

$\mathrm{E}_{\mathrm{c}}=3200 \sqrt{\mathrm{f}_{\mathrm{c}}^{\prime}}+6900$

$\mathrm{MPa}(\mathrm{ACI})$

The calculated values of theoretical and experimental cracked moment of inertia for HSC tested beams are presented in Table 5 .
Table 5: Theoretical and experimental cracked moment of inertia for

Maximum deflection at service load: To investigate the service load behavior with respect to deflection, maximum (midspan) deflection, $\delta_{\mathrm{s}, \mathrm{cal}}$, at service load are calculated for HSC test beams, using the elastic bending theory as:

$$
\delta_{\mathrm{s}, \mathrm{cal}}=\frac{\mathrm{M}_{\mathrm{a}}}{24 \mathrm{E}_{\mathrm{c}} \mathrm{I}}\left(3 \mathrm{~L}^{2}-4 \mathrm{a}^{2}\right)
$$

To assume the service load for calculating $\delta_{\mathrm{s}, \mathrm{cal}}$ in Eq. 5, the experimental ultimate load divided by a factor of 1.7 was considered. This is similar to suggested value used by ${ }^{[9]}$.

Where

$\mathrm{M}_{\mathrm{a}}=$ The applied maximum (midspan) moment

$\mathrm{L}=$ The beam span

$\mathrm{a}=$ The shear span

$\mathrm{E}_{\mathrm{c}}=$ The modulus of elasticity of concrete

The value suggested by ACI Code is used as:

$$
\mathrm{E}_{\mathrm{c}}=3200 \sqrt{\mathrm{f}_{\mathrm{c}}^{\prime}}+6900
$$

$\operatorname{MPa}(\mathrm{ACI})$

$\mathrm{I}=$ the moment of inertia, is taken as that specified by $\operatorname{code}^{[8]}$ for effective moment of inertia, $\mathrm{I}_{\mathrm{e}}$ as:

$$
I_{e}=\left(\frac{M_{c r}}{M_{a}}\right)^{3} I_{g}+\left[1-\left(\frac{M_{c r}}{M_{a}}\right)\right] I_{c r} \leq I_{g}
$$

$\mathbf{M}_{\mathrm{a}}=$ Maximum applied moment at a stage that deflection is computed

$\mathrm{M}_{\mathrm{cr}}=$ Cracking moment of beam (i.e., Eq. 1)

$\mathrm{M}_{\mathrm{cr}}$ is cracking moment and the values for code are presented in Table 3.

The maximum deflection $\delta_{\mathrm{s}, \mathrm{cal}}$, measured at the midspan with Eq. 5 at the assumed service load is presented in Table 6 . In Table 6 the experimental maximum deflection are compared with the corresponding predicted value, denoted as $\delta_{\mathrm{s}, \exp }$.

Maximum Crack Width at Service Load: The maximum crack width, $\mathrm{w}_{\mathrm{cr}, \exp }$, measured at the center of 
Am. J. Applied Sci., 5 (9): 1135-1140, 2008

Table 6: Theoretical and experimental maximum deflection at service

\begin{tabular}{|c|c|c|c|}
\hline \multirow{2}{*}{\multicolumn{4}{|c|}{$\mathrm{F}_{\mathrm{s}}=\mathrm{P}_{\mathrm{u}(\exp )} / 1.7(\mathrm{kN})$}} \\
\hline & & & \\
\hline BC6 & 7.87 & 3.46 & 608.89 \\
\hline B6 & 5.67 & 3.19 & 561.41 \\
\hline BC7 & 10.66 & 3.51 & 723.23 \\
\hline B7 & 6.86 & 2.95 & 608.34 \\
\hline BC 8 & 7.87 & 3.57 & 766.53 \\
\hline B8 & 7.22 & 3.55 & 737.10 \\
\hline
\end{tabular}

Table 7: Theoretical and experimental maximum crack width at service load

\begin{tabular}{lllll}
\hline Beam & $\begin{array}{l}\text { First } \\
\text { observed crack } \\
\text { width }(\mathrm{mm})\end{array}$ & $\omega_{\text {cr,exp }}(\mathrm{mm})$ & $\omega_{\text {cr,G\&L }}(\mathrm{mm})$ & $\begin{array}{l}\mathrm{F}_{\mathrm{s}}=\mathrm{P}_{\mathrm{u}(\exp )} / \\
1.7(\mathrm{kN})\end{array}$ \\
\hline BC6 & 0.10 & 0.30 & 0.28 & 608.89 \\
B6 & 0.10 & 0.29 & 0.20 & 561.41 \\
BC7 & 0.02 & 0.40 & 0.25 & 723.23 \\
B7 & 0.06 & 0.32 & 0.16 & 608.34 \\
BC8 & 0.02 & 0.38 & 0.24 & 766.53 \\
B8 & 0.06 & 0.31 & 0.16 & 737.10 \\
\hline
\end{tabular}
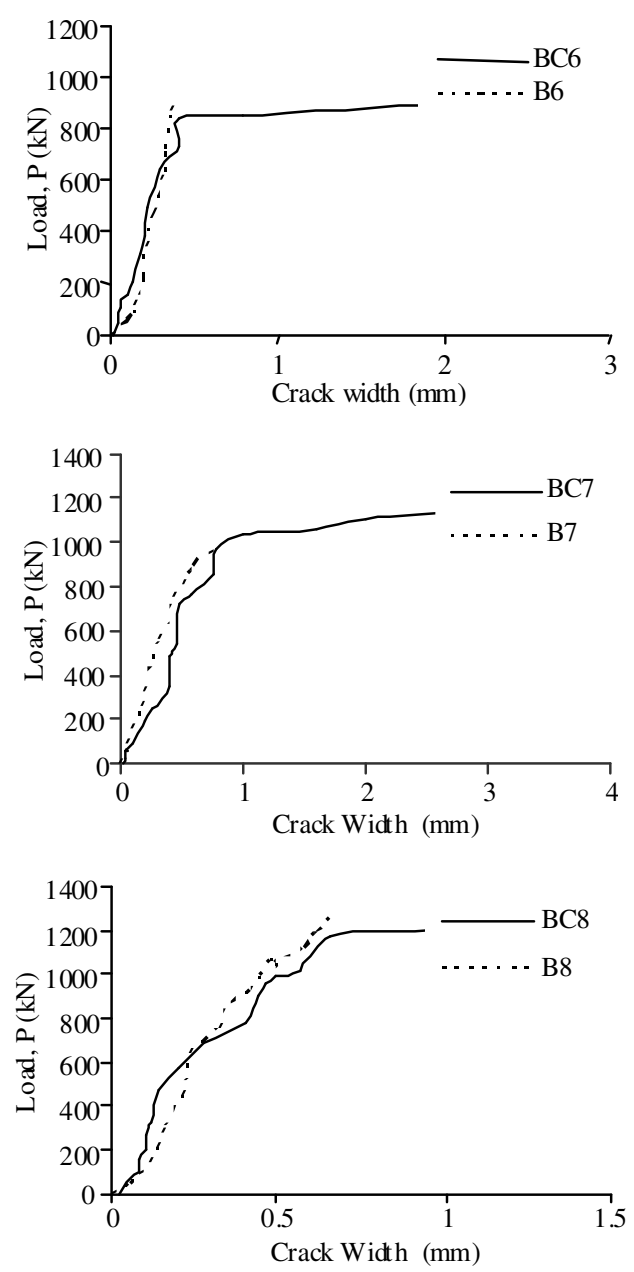

Fig. 3: Load versus max crack width for HSC test beams
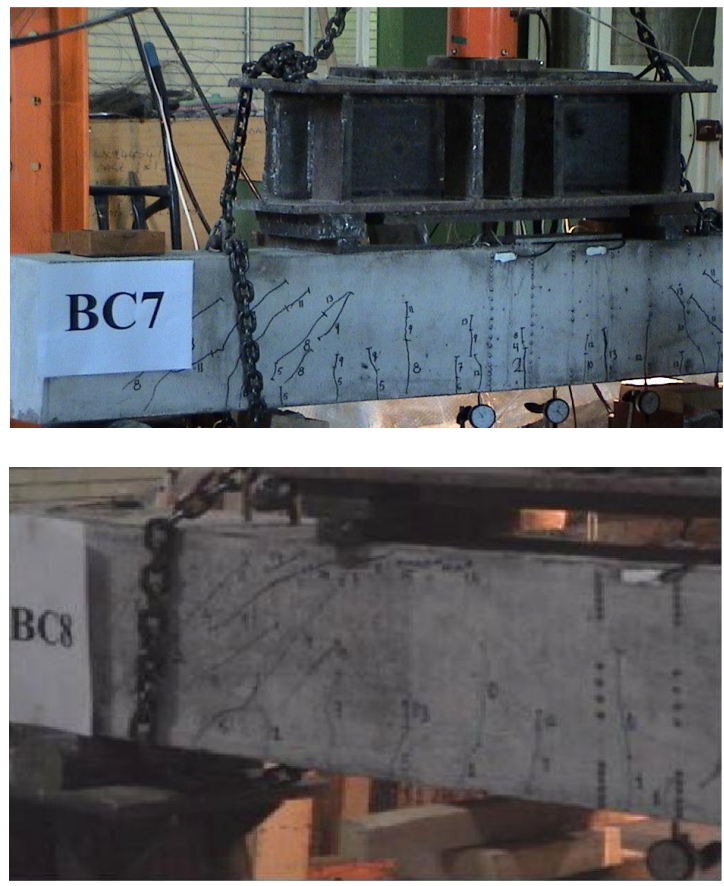

Fig. 4: Crack propagation of the beams under service load

the bottom layer of tensile reinforcement at the assumed service load is presented in Table 7. For analytical evaluation, expression suggested by Gergly and Lutz ${ }^{[18]}$ has been chosen for assessment. In Table 7 the experimental maximum crack widths are compared with the corresponding predicted value, denoted as $\mathrm{w}_{\mathrm{cr}, \mathrm{G}}$ and L. in Fig. 3 the load versus width crack curve for B and $\mathrm{BC}$ beams is showen and in Fig. 4 Behavior and propagation of crack under the service load is shown.

\section{CONCLUSION}

For HSC with heavily steel reinforced concrete beams the following conclusions can be result:

- The experimental cracking moment is lower than theoretical values two codes ACI, CSA and the suggested value by ${ }^{[5]}$

- The neutral axis in doubly reinforced beams in crack, yield and ultimate stages is decreased

- $\mathrm{I}_{\mathrm{cr}(\mathrm{th})}$ is larger than $\mathrm{I}_{\mathrm{cr}(\exp 1)}$ and $\operatorname{Icr}_{(\exp 2)}$

- Deflection at service load in doubly reinforced beams is larger than singly reinforced beams and $\delta_{\mathrm{s}, \text { exp }}$ is larger than $\delta_{\mathrm{s}, \mathrm{cal}}$

- Width crack at service load in doubly reinforced beams is larger than singly reinforced beams and $\omega_{\text {cr,exp }}$ is larger than $\omega_{\mathrm{cr}, \mathrm{G}}$ and $\mathrm{L}$ 


\section{REFERENCES}

1. Ashour, S.A., 2000. Effect of Compressive Strength and Tensile Reinforcement Ratio on Flexural Behavior of High-Strength Concrete Beams: Engineering Structures, 22 (5): 413-423.

2. Mansur, M.A., M.S. Chin and T.H. Wee, 1997. Flexural Behavior of High-Strength Concrete Beams: ACI Structural J., 94 (6): 663-674.

3. Sarker, S., O. Adwan and J.G.L. Munday, 1997. High Strength Concrete an Investigation of the Flexural Behavior of High Strength RC Beams: The Structural Engineer, 75 (7): 115-121.

4. Paulson, K.A., A.H. Nilson and K.C. Hover, 1989. Immediate and Long-Term Deflection of High Strength Concrete Beams: Research Report No. 893, Department of Structural Engineering, Cornell University, Ithaca, N.Y., pp: 230.

5. Maghsoudi, A.A., H. Akbarzadeh, 2006. Flexural ductility of HSC members: Structural Eng. and Mechanics, an Int. J., 24 (2).

6. Maghsoudi, A.A. and H. Akbarzadeh, Diagonal Compression Criterion on Compression Reinforcement ratio In Flexural HSRC Members: ACI Structural J.

7. ACI Committee 318, 2002. Building Code Requirement for Structural Concrete (ACI 318-02) and Commentary (318R-02): American Concrete Institute, Farmington Hills, Mich., 443.

8. ACI Committee 363, 1992. Review of ACI Code for Possible Revisions for High-Strength Concrete (ACI 362R-92): American Concrete Institute, Detroit.

9. Rashid, M.A. and M.A. Mansur, 2005. Reinforced High-Strength Concrete Beams in Flexure: ACI Structural J., 102 (3):462-471.
10. CSA 94, CSA Technical Committee, 1994. Design of Concrete Structure for Buildings: CAN3-A23.3M94, Canadian Standards Association, Rexdale, Ontario.

11. Rashid, M.A., M.A. Mansure and P. Paramasivan, 2002. Correlations between Mechanical Properties of High Strength Concrete: J. Mater. Civil Eng., ASCE, 14 (3): 230-238.

12. Gilbert, R.I., 1999. Deflection Calculation for Reinforced Concrete Structures-Why We Sometimes Get It Wrong: ACI Structural J., 96 (6): 1027-1032.

13. Gilbert, R.I., 1998. Serviceability Considerations and Requirements for High Performance Reinforced Concrete Slabs: International Conference on High Performance High Strength Concrete, Perth, Australia, pp: 425-439.

14. Large, G.E. and T.Y. Chen, 1969. Reinforced Concrete Design, The Ronald Press Co., New York, 1969, pp: 481-497.

15. Ashour, S.A., F.F. Wafa and M.I. Kamal, 2000. Effect of the Concrete Compressive Strength and Tensile Reinforcement Ratio on Flexural Behavior of Fibrous Concrete Beams: Engineering Structures, 22 (5): 1145-1158.

16. Macgregor, I.G., 1988. Reinforced Concrete Mechanics and Design: New Jersey (USA), Prentice-Hall International.

17. Ghali, A., 1993. Deflection of Reinforced Concrete Members: A Critical Review: ACI Structural J., 90 (4): 364-373.

18. Gergely, P. and L.A. Lutz, 1968. Maximum Crack Width in Reinforced Concrete Flexural Members: Causes, Mechanism and Control of Cracking in Concrete, SP-20, R.E. Philleo, Edn., American Concrete Institute, Farmington Hills, Mich., pp: 87-117. 